Cinémas

Revue d'études cinématographiques

Journal of Film Studies

\title{
Films, Tangos and Cultural Practices
}

\section{Richard A. Young}

Volume 7, numéro 1-2, automne 1996

URI : https://id.erudit.org/iderudit/1000939ar

DOI : https://doi.org/10.7202/1000939ar

Aller au sommaire du numéro

\section{Éditeur(s)}

Cinémas

ISSN

1181-6945 (imprimé)

1705-6500 (numérique)

Découvrir la revue

Citer cet article

Young, R. A. (1996). Films, Tangos and Cultural Practices. Cinémas, 7(1-2), 187-203. https://doi.org/10.7202/1000939ar

\section{Résumé de l'article}

Bien qu'associé d'abord à la culture urbaine de Buenos Aires dans la première partie du siècle, le tango s'est internationalisé et a acquis des significations qui lui permettent d'être compris dans d'autres contextes. En particulier, depuis l'époque de Valentino, il a été intégré au cinéma international, où il est perçu non seulement comme une pratique culturelle qui exprime le désir et la sensualité, mais comme un signe qui génère son sens en rapport à d'autres signes et d'autres manifestations. Commençant ainsi avec la considération de la pratique culturelle comme répétition et variation, cet article va faire état de plusieurs films dans lesquels le tango n'est pas seulement utilisé comme motif, mais repose sur la compréhension que nous avons de lui dans d'autres contextes et parfois d'autres films dans lesquels il est apparu. 


\section{Films, Tangos and Cultural Practices}

\section{Richard A. Young}

\section{RÉSUMÉ}

Bien qu'associé d'abord à la culture urbaine de Buenos Aires dans la première partie du siècle, le tango s'est internationnalisé et a acquis des significations qui lui permettent d'être compris dans d'autres contextes. En particulier, depuis l'époque de Valentino, il a été intégré au cinéma international, où il est perçu non seulement comme une pratique culturelle qui exprime le désir et la sensualité, mais comme un signe qui génère son sens en rapport à d'autres signes et d'autres manifestations. Commençant ainsi avec la considération de la pratique culturelle comme répétition et variation, cet article va faire état de plusieurs films dans lesquels le tango n'est pas seulement utilisé comme motif, mais repose sur la compréhension que nous avons de lui dans d'autres contextes et parfois d'autres films dans lesquels il est apparu.

\section{ABSTRACT}

Although first associated with the urban culture of Buenos Aires in the early part of this century, tango has become internationalized and has acquired meanings that permit it to be understood in other contexts. In particular, since the time of Valentino, it has become accommodated to the international cinema, where it is viewed not only as a cultural practice that expresses desire and sensuality, but as a sign that generates its meaning in part from other signs and other manifestations of the same sign. Beginning therefore with a consideration of cultural practice as repetition and variation, this paper will comment on several films in which 
tango is not only used as a motif but relies for our understanding of it on other contexts and sometimes other films in which tango has appeared.

Tango is a rite

Bernardo Bertolucci

Last Tango in Paris

In a relatively slim volume titled How Societies Remember, Paul Connerton examines social or collective memory from two different perspectives: the performative rituals of commemorative ceremonies, through which societies formally honour and perpetuate the memories that are the external manifestations of their underlying ideologies and structures; and the bodily practices of everyday life, learned habits, consciously and unconsciously performed, that regulate social conduct and are inscribed with cultural value. The two categories are not mutually exclusive. They overlap and intertwine, and both are cultural practices in their own way, but I shall be concerned here with social phenomena that, were I to locate them anywhere, I would place primarily in the second of Connerton's two categories, not among the rites of Religion and State, but among the smaller rites or ceremonies of daily living.

Cultural practices are much like the lexicon of a language. Each is endowed with a range of potential meanings shared by its users and, like any sign, is susceptible to modification not only through collective use over time, but through the particular combinations of signs or practices struck by individual use in given contexts. This paper, for example, comes to its readers as a practice conforming to the norms of academic publishing in a learned journal as adopted by the $C R C L / R C L C$. It was originally given, however, within a university lecture series in a way that drew attention to the character of the academic lecture itself as a cultural practice as susceptible to variation as other practices. The parameters of the series in question, established by local custom and the conventions of academia, were transgressed in several ways. The use of a theatre for the occasion not only 
served the practical purpose of facilitating delivery of audiovisual elements in the presentation, but also signalled a shift from a standard lecture/seminar format towards a style, including music, film, and a brief lapse into song by the presenter, more frequently associated with certain kinds of performance. Moreover, this association was furthered by the absence of any kind of introduction of the speaker to the audience and the playing of recorded music before the lecture began. While the lack of any preliminary remarks by the organizer of the lecture series gave an unexpectedly literal - therefore transgressive rendering of the cliché that "the speaker needs no introduction," the music playing as the audience entered and found their seats served a function borrowed from other contexts. As either background or foreground, it was intended to set a mood, to anticipate like an overture at the opera, to create the amenable atmosphere of the salon or a Palm Court Café, or perhaps, in anticipation of the film clips that punctuated the lecture, merely to mimic the mores of the cinema, where music fills the air between the popcorn and the curtained screen ahead of the waiting viewer.

If I have lingered on the circumstances of initial presentation of this paper, it is to indicate how shifts in custom and context demonstrate the potential fluidity even of the academic lecture as cultural practice and show how one practice, "more honour'd in the breach than the observance," as it were, may easily slide into another. There is a slipperiness to cultural practices that is especially challenging and potentially disorienting, and the term itself is allusive of a clinical preciseness that their character belies. With respect to culture, suffice it to repeat, without pursuing the concept further on this occasion, that the culture to which I am referring here is the small " $c$ " culture of the everyday, whether it manifests itself in grand form or in the commonplace. Practice is also a complex term, but the idea uppermost in my mind when I find it in the phrase "cultural practices" is, as in Connerton's book, ' the notion of repetition. It is the iterativity of culture that makes a practice of it, such that the singularity of each manifestation of a cultural paradigm is both undermined and reinforced by its character as a 
retextualization and a re-contextualization of a preceding event. My comments about academic lectures are not only a case in point, but a demonstration of the infinite capacity of variation in repetition and, therefore, of the inexhaustibility of cultural practice. Yet while we detect, create, and respond to repetition, culture eludes us. There is no object that can call itself culture, and what we study is not culture itself but the repeating forms of cultural investiture of persons, places, objects and events. Culture, like time, lacks autonomous phenomenological existence (what is a handful of time or a tub of culture?) and acquires identity and shape solely in the phenomena it invests. For those of us who share an interest in artefacts such as film, literature, photos, or paintings - textualizations of cultural practices at the same time as they are cultural practices in their own right - , we find ourselves at yet another remove: we do not study an event or an object per se and its investiture with cultural value, but the secondary process of textualization of cultural texts through certain kinds of discourse. Thus, while my activity may be defined, for the purposes of describing the academic activity in which I am engaged, as the study of cultural practices, I suspect that what I am really pursuing could be more appropriately, although more clumsily, described as the study of the textual and contextual practices of cultural investiture.

The opening scene of Steven Spielberg's Schindler's List (1993) is set in Cracow in 1939. About two minutes into the film, Oskar Schindler enters a nightclub and as the camera begins to pan around the room and its occupants, a small orchestra strikes up a tango. The piece in question is "Por una cabeza," a tango with lyrics by Alfredo Le Pera and music by Carlos Gardel, recorded by Gardel in 1935 and sung by him in the film Tango Bar which was shot in Paramount's Long Island studios and released in the same year as his recording on the Victor label. ${ }^{2}$

Under what circumstances and for what purpose was this piece of music included in the film? Perhaps it derived from an intuitively Hollywood sense of cultural practice: "Mr. Spielberg, what do you want for the nightclub?" "Whad'ya suggest?" "How about a small orchestra; three, four pieces; something 
thirties; a foxtrot." "No, no, not a foxtrot; something moodier, seamier, more sinister; a tango. Yeah..., gimme a tango." Perhaps not. Perhaps the scene in the nightclub is underscored by its historical authenticity and that "Por una cabeza" was played the very night in 1939 that Oskar Schindler launched his bid to make a fortune in pots and pans in occupied Cracow. Obviously, I am not sure, and I am also very sceptical. The scene does not figure in Thomas Keneally's documentary novel that served as Speilberg's primary source. Among the losses of cultural illusion I have experienced, the discovery that Robert Doisneau's 1950 photograph "Le Baiser de l'Hôtel de Ville" is an utter fake ranks fairly high. This quintessential image of romantic Paris, a couple embracing in the broad light of day as the world rushes by, was not only posed by models, but the man in the photo was not even French: he was an Irishman who eventually settled in Australia, raised a family, grew old, and died. Perhaps he always had Paris, but the Paris he really had was just as likely not the one of his photograph. This discrepancy between the real and the image, between the experience and its textualization, is not accidental, but a consequence of the interference of memory under the influence of cultural practice, such that a recollection may acquire greater value and meaning than the lived experienced. The point was succinctly put by Julio Cortázar in one of the last stories he ever wrote: "Absurdo que ahora quiera contar algo que no fui capaz de conocer bien mientras estaba sucediendo, como en una parodia de Proust pretendo entrar en el recuerdo como no entré en la vida para al fin vivirla de veras." ${ }^{3}$

The tango played at the beginning of Schindler's List captures a cultural practice of the 1930's and is one of the signifiers of a nightclub of that period, even during wartime and in a city under occupation, but as a consequence of the contexts of its textualization and the associations it forms within the scene to which it belongs, it also contributes a meaning that surpasses its purely historical connotations and could only be derived retrospectively, not only after the viewer has seen the entire film, but by viewing it from the perspective of the present looking back to the time when the events of the film are set. The voice of the 
tango (only implied in the movie, because the tango is not sung in Spielberg's version) is that of an inveterate gambler, always ready to fall for a pretty face, knowing he'll likely get burned, and always ready to put all his money on a horse while knowing he'll probably lose his shirt. In the context of the film, the gambling womanizer to whom the tango alludes is Schindler, although the association is not fully formed till later, when his personality and history have emerged more clearly. Yet this and other connections made even at this stage of the film establish and anticipate directions to be taken by the unfolding story. Spielberg's black and white images, just because they are black and white, not only evoke the newsreels or documentary footage of the period they represent, but have inevitable historical connotations of classic cinema of the pre-war period. In particular, given the strains of the tango in the soundtrack, the image of Schindler laying out money to ingratiate himself with German officers compares with the image of the character played by Gardel in Tango Bar placing his bet at the racetrack while "Por una cabeza" continues in the background. Moreover, the fistful of bills with which Schindler opens his gamble will turn into the money he eventually hands over to buy the lives of his Jewish workers. This transaction, so many Jews bought at so much a head, so much money "por una cabeza," " gives an unexpected twist to the title of the tango heard in the nightclub scene at the beginning of the film. The shift in meaning, however, is also a token of the shift in the sense of moral responsibility undergone by Schindler and an indication of the values advocated by the film: from the gambling womanizer suggested by the Le Pera/ Gardel tango and his own conduct, Schindler evolves into a man who, rather than celebrating the twelve hundred lives he saved, regrets the one life he failed to preserve because he didn't do more.

Although these comments on the presence of a tango in Schindler's List could undoubtedly be extended and lead to broader questions concerning the textualization of history in the film that would eventually draw me into the polemic that has developed around Spielberg's work, ${ }^{5}$ I will limit myself to a couple of rather evident observations. As a cultural practice 
which is already a textualization of other practices, the tango is not a limited cultural sign. It has a voluminous semantic baggage, a cargo that it carries forward either in whole or in part when it too is textualized, and, in the new context in which it is located, this load is drawn into an intricate interplay of old and new meanings that is itself the essence of cultural practice as the iterative display of old values in new environments from which new practices emerge. The examples I will turn to will pursue the point, although less dramatically perhaps than the one taken from Schindler's List.

Ettore Scola's 1983 film Le Bal is a series of historical vignettes, all located in the same dance hall, telling the story of the twentieth-century through popular dance music from before the First World War to disco. The passage of time is marked by the shifting tides of fashion in music, clothes, and customs, while the events of the world at large intrude upon the dance floor and are reflected in the attitudes and interactions of the dancers. In a film which is itself a remarkable source for the study of cul-

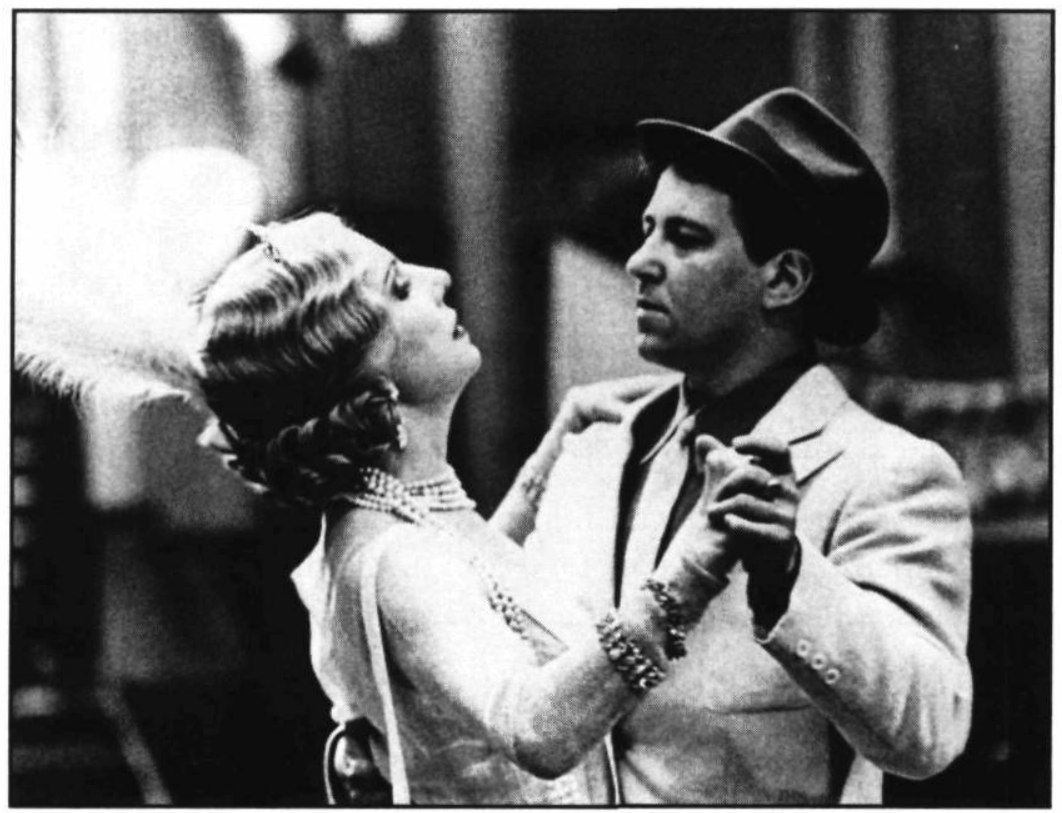

Le Bal d'Ettore Scola (1983)

Collection Cinémathèque québécoise

Films, Tangos and Cultural Practices 
tural practices, the tango is featured twice, once towards the beginning of the film and again in the vignette for 1956.

The popularity of the tango in Paris from about 1914 until the outbreak of the Second World War proved significant not just because of what it meant for the internationalization of the form, but because it also impacted on the reception and development of the tango in South America. Among other factors, it gave a cachet of respectability to what had hitherto been tainted by association with prostitution and the café culture of the working class barrios (or arrabales) of immigrants to Buenos Aires and Montevideo. On the one hand, the need for a seal of approval from Paris is an indicator of the inhibiting selfconsciousness of a post-colonial culture, while, on the other, it serves as a reminder of the complex cross-currents underlying the formation of cultural practices. However, rather than dwelling on aspects of the history of tango, it will be more helpful to see what can be learned about its cultural dimensions from the tango danced in the 1956 vignette of Le Bal.

Although the inclusion of a tango in the vignette associated with this date arises from an historically accurate reflexion of the popularity of Latin dance music in the mid-fifties, the caricaturesque representation of stereotypes is also the product of a process of cultural appropriation that has a longer history. Members of the ballroom orchestra in this segment of the film are dressed in generic fiesta style, allusive of a carnival in either Río or the Caribbean, and are called "Los Acapulco's Boys", a title that, with its mix of Spanish and English and initially confusing apostrophe, also reveals an attempt to accommodate the cultural specificity of the other to a more dominant, generalizing code. In fact, the tango as cultural practice in a European context owes something to a cinematic tradition that has caused it to diverge from its South American counterpart in light of other roots. The tango danced in Le Bal is not performed in traditional South American manner, but is choreographed in accordance with a ballroom stylization that was profoundly influenced by Rudolph Valentino's performance in the 1921 film The Four Horsemen of the Apocalypse. The caricatured image of a Valentino-style Latin lover, with up-cast eyes and attempted al- 
lure of suave sophistication sets the tone of the tango in Le Bal as it begins, and the entire scene is an intricate ballet of matching and mismatching drawing on the broader semantic range of the term "tango," which not only denotes a particular dance form but connotes flirtation and amorous entanglement.

The music to which the couples spin around the floor is a piece called "Hernando's Hideaway," composed by Richard Adler, with lyrics by Jerry Ross, and originally written in 1954 for a Broadway musical called The Pyjama Game, subsequently made into a movie with Doris Day. Both as a song and a dance tune, " Hernando's Hideaway" was very popular in the mid-fifties. The lyrics may not be as memorable as some of those by Cole Porter or the Gershwins, but they are revealing: "I know a dark, secluded place / a place where no-one knows your face; / a glass of wine, a quick embrace; / it's called Hernando's Hideaway, o-lay." Reference to a love nest or place of assignation is common enough in the South American tango, but the "olé" at the end of the verse here betrays Spanish associations, and the misspelling of the word in the sheet music ("o-lay" instead of "olé"), may be read as either linguistic appropriation by the lyricist, similar to that among "Los Acapulco's Boys," or a pun that displays an evidently erotic secondary meaning quite compatible with the semantic range of tango lyrics. This and further references to castanettes and pirouettes in the lyrics are reminders that the tango is not exclusively South American. Not only is there a Spanish tango, associated with the Spanish form of light opera known as the zarzuela and sometimes referred to as the "tango andaluz," but the European tango in general, fostered by an image of the bolero costumed Valentino of silent film, frequently has Spanish rather than Argentinean connotations. As exemplified by the tango performed in Le Bal, its semantic field is more that of the discourse of seduction, than that of social or political engagement. The difference is interestingly highlighted by the reception given to an album of tangos recorded by Plácido Domingo in the early eighties. Although immensely popular internationally, it was also criticized among certain tangueros on account of the singer's preference for lyric sentimentality over description of life in the barrio. 
As a received symbol of eroticism and entanglement, and not just sexual or emotional entanglement, the tango is used almost routinely in many films. The 1988 adventure/gangster movie Two to Tango, directed by Hector Olivera, starring Don Stroud and Adrienne Sachs, is a good example. Conrad (played by Stroud) is a hitman sent to Buenos Aires by The Company to eliminate a rival mob leader. But he is a weary warrior, tired of killing, ready to make this assignment his last before escaping to the refuge chosen for himself in the East. While he maintains surveillance he also meets and begins an affair with his target's girlfriend, a dancer at a tango bar, who just happens to be an American and is just as anxious to escape. However, as Conrad stalks his prey, he is also stalked. His new girlfriend and the owner of the bar where she dances are both shot and when he finally confronts his prey he discovers that he too has been under close surveillance. The tables are turned and just before he is shot by the man whom he was sent to kill he is reminded by his assailant that it takes two to tango.

Although not in the final words, but in one of its last scenes, Last Tango in Paris (1972) also contains an allusion to its title. In both films, the tango motif is used for its associations with intrigue, violence, and eroticism. But the similarity stops there. Bernardo Bertolucci's film has perpetuated and enriched the motif in a way that has affected its subsequent meaning and likely accommodated it for use in later films, such as Two to Tango, a movie to which my preceding comments have evidently not done justice. By the same token, a full reading of Last Tango in Paris undertaken in association with dance and in relation to the lyrics of some of the most traditional South American tangos is also beyond the scope and purpose of this commentary. In its place, I will offer a few general observations on the role of the tango in the textualization of the story told in the film.

Although the dance is mentioned in the title, the meaning that the tango has for the film as a whole does not become clear until that scene towards the end when Paul and his young lover find their way into a dancehall and disrupt a ballroom dancing competition before they leave. Throughout this scene, there is a 
counterpoint sustained between the plight of the two principal characters and the tango competition, turning the latter into an ironic commentary on the former and making it possible to attribute a particular textual quality to the events of the film. The tango danced by the couples in the competition is choreographed in modern ballroom style. The quick, nervously frenetic movements of the dancers give them the look of automotons who move to the music, but studiously avoid the gaze of their partners as if protecting their anonymity and not really dancing with each other. Like the lovers of the film, they engage together in an act without engaging their partner. As such, the tango becomes retrospectively a metaphor of the sexual encounters presented earlier in the film at the same time as it is offered as a symbol of sexual involvement without emotional compromise. When Paul tries to justify his conduct on the dance floor by referring to love, he is curtly reminded by the mistress of ceremonies that the event he has disrupted is not about love but is a competition. If he wants love he should go to the movies, which is where Paul's sexual partner finds it, eventually deciding to marry the director of the film in which she is performing.

At the same time as the particular elements brought into play in the film re-contextualize practices associated with the tango, they also invoke a number of traditional texts. The title of the film is alluded to within the film in a way that strengthens the metaphorical relation between the tango and the story events. When the last round in the tango competition is announced with the words "Bonne chance pour le denier tango!" they also refer ironically to Paul's unsuccessful attempt to renew his affair and move it to a different plane. The title of the film also evokes the historical association of the tango with Paris with respect to both its evolution and allusions to the city in some of its best known lyrics. ${ }^{6}$ Similarly, location of the story in Paris and reference to the city in the title in the same context as reference to the tango draw on the connotations of love and sexual freedom conventionally associated with the city since its Bohemian lifestyle of the mid-nineteenth century was first popularized in literature. Finally, it should not escape our attention that Last Tango in Paris draws upon an essentially masculine narrative. Paul's 
relations with women combine exploitation with emotional entanglement. His ownership of a hotel or flophouse regularly used by prostitutes makes him, like the protagonist of a traditional tango, a pimp in all but name. Moreover, like his counterpart in the tango, he is stereotipically characterized as a despairing, lachrymose male driven to deep depression through feelings of betrayal and abandonment by his lover. Just as his wife has betrayed him with others and abandonned him through suicide, acts he is unable to comprehend, he is also abandonned by his younger lover, who has not only resolved to marry another but makes their separation irrevocable by shooting him.

The performance of "Hernando's Hideaway" in Le Bal and the use of the tango motif in Two to Tango and Last Tango in Paris are all variations on the themes of intrigue and eroticism, but comparison of these films with Fernando Solanas's L'Exil de Gardel (1988) also reveals that they engage only part of the tango's potential semantic field. By the time the South American tango entered its golden age, from the early twenties to about the late thirties, it had already a become cultural practice in the second degree. I mean to say that it was an active cultural form still practised in the everyday life of Buenos Aires and Montevideo, at the same time as it was a textualization of the cultural practices it represented through its music and lyrics. It had already become a consciously self-reflexive form, with an established language, an established content, and a capacity both to evoke pre-conceived images of the past and to refer to its own capacity for evocation. It had become, in fact, the musical or lyric equivalent of a Doisneau photograph or Cortázar's absurdly Proustian parody: a textualized memory with more meaning as memory than the corresponding experience it evoked.

This was precisely the quality - the tango as a musical genre whose essence is the constant re-textualization and re-contextualization of preceding events - that made it an apt vehicle for Solanas's representation of Argentinean exile from dictatorship. Both literally and symbolically - through the tanguedia, or tango spectacle they are preparing to stage, and through the incidents of their own lives —, the characters of Solanas's film live 
out their exile in Paris as a pastiche collage of tango lyrics. The movie contains several tangos, including traditional songs presented in original Gardel recordings. However, one of the most striking characteristics of the film with respect to the perpetuation of cultural practices is not just how old songs are given new meanings, but how old meanings are given new songs and the tango tradition passes to other generations and contexts, to the children of Gardel in exile, as it were, and then to their children, those for whom exile is home.

"Solo" is one of those new songs, a tango written for the film with lyrics by Fernando Solanas and music by Astor Piazzolla. Yet, although a new composition, "Solo" has several unmistakably traditional elements. It is inserted in the film in such a way that it acquires a prologue and a context that address two clichés of the tango: the return of the profligate and the figure of a long-suffering mother. When Juan Dos phones Buenos Aires from Paris he learns of his mother's death and experiences feelings of remorse both for the pain he has caused her and for not having returned home in time. The relation between mother and son seems almost archetypically Jungian, but is typical of the genre and provides the context of a return from exile in which "Solo" is presented. The themes of the lyrics to "Solo," abandon, solitude, sex and alcohol, exile and return, nostalgia for other times and places, especially childhood and youth in the crowded barrios of Buenos Aires, are all familiar, both with respect to their presence and how they are presented in the film, notwithstanding a certain tendency toward the surreal. Even the inclusion of flashbacks in the performance of the tango to create a collage of images showing how the past impinges on the present is reminiscent of tango movies of the thirties. All this would seem to make "Solo," with its social bite and eminently pessimistic tone, a far cry from "Hernando's Hideaway," but there are places where the embittered nostalgia of the Argentinean tango and the discourse of seduction uppermost in some of its European counterparts intersect and combine.

The 1992 Universal Pictures Scent of a Woman, directed by Martin Brest and starring $\mathrm{Al} \mathrm{Pacino,} \mathrm{is} \mathrm{a} \mathrm{coming-of-age} \mathrm{film}$ about male bonding centred on traditional codes of masculinity. 
Charlie is a high school student socially and financially out of his depth at an upper class boarding school, where he is confronted one Thanksgiving Weekend with a dilemma : either to inform on his prankster friends or suffer the consequences of their misdemeanour which would result in disgrace and expulsion from the school in spite of his innocence. Frank is a retired US army colonel, blinded in an accident and now so convinced of his uselessness that he decides on one last fling before ending his life. Thus Charlie, who has been hired to look after Frank for the weekend, finds that the job not only takes him to New York, but also through some unexpected turns, including a hairraising ride in a sports car with the sightless colonel at the wheel. At one point Frank invites Charlie into a hotel for a drink and the scene that unfolds in the bar, like the car ride, is a mini-drama in its own right.

The music, running almost uninterruptedly throughout the scene, is a set of very popular South American tangos, mostly from the twenties, but played by a five-piece orchestra of strings, piano and accordion with the instrumentation and manner of the salon, Grand Hotel, or Palm Court rather than of an "orquesta típica" of Buenos Aires. This style, different from either Latin ballroom dance or Piazzolla's orchestrations heard respectively in Le Bal and L'Exil de Gardel, is nonetheless already indicative of appropriation by one culture of the forms of expression of another. The music fluctuates between background and foreground, occupying the gaps in conversation and at times taking centre stage as the characters both refer and are subordinated to it. There is an intricate counterpoint, not unlike that at the end of Last Tango in Paris, a dance, as it were, between the specific conduct of the characters that unfolds in the scene and a textualization through music and the lyrics they imply of the kind of behaviour displayed on screen.

Frank's instinctually erotic response to the scent of a woman sets the tone for this mini-drama within the film, although the tango playing at the time, while Frank and Charlie are seated on their own at a table, ironically predicts the pessimistic conclusion of the scene: "Caminito," the tango in question, is not a song of anticipation, but a lament for lost times, for roads al- 
ready travelled, and a lover who has left. After this prologue comes the flirtation, a conversation of hesitations and double meanings that takes place after Frank and Charlie have joined Donna at her table. When the conversation, mainly between Frank and Donna, turns to tangos, it has an erotic subtext, that needs no commentary. The nature of their exchange and its implied meaning is already underscored by the music. As Frank and Charlie moved towards Donna's table, "Caminito" ended and "A media luz" began, a tango describing what was euphemistically referred to as a garçonnière, an establishment for the entertainment of unattached males. In this instance, it refers, not to Corrientes 348, the Buenos Aires address in Carlos Lenzi's 1925 lyrics, but to the scene unfolding in Scent of a Woman and the sexual habits of Frank, who immediately after this meeting with Donna leaves Charlie waiting in a hired limousine while he visits a callgirl. Before that, however, seduction follows flirtation: Donna and Frank move onto the dance floor and tango. The music is "Por una cabeza," the same piece that Spielberg used for the beginning of Schindler's List, although here it epitomizes the womanizer in Frank at the same time as it anticipates the downturn in mood at the end of the scene. Donna and Frank have barely left the dance floor when Michael arrives and she leaves with him. Not only is Michael the antithesis of Frank, as we already knew, but his departure with Donna to meet Daren and Carol in the Village is a reminder of the abandonned male in many a tango whose lover is attracted to wealthier men and nightspots more fashionable than the lamplit streets of the arrabal. Moreover, as "Por una cabeza" concluded, the orchestra began another, perhaps better known tango, "Adios muchachos." Its title is an apparent comment on Donna's hasty departure with Michael, but its lyrics are the farewell address of a subject to his past and his friends before facing his own final departure: Frank on a final fling, before putting an end to it all.

There is certainly more to be said about this scene and the tango tradition of the South it evokes: Al Pacino's macho assertiveness, his Latin looks, sleeked hair and sartorial fastidiousness as representations of a certain porteño or Buenos Aires type; the 
choreography of the dance, with the intricate stepping of the South American tango, in which the male is not so much dancing with his partner, as he is displaying himself and his ability, an attitude akin to that I have already noted with respect to Last Tango in Paris. There is also something to be said, both in Scent of a Woman and in Last Tango in Paris, about female complicity in the realization of the role of the male, but if I leave that to one side, it is because Scent of a Woman is, above all, about masculinity. In fact, what is especially noteworthy here is that in a movie set in the US with the central theme of male role modelling, using several traditional codes of masculinity, including those of the army and the school, as well as the relation of the male to his car, one of these codes is drawn from a traditional Hispanic context, not in order to appropriate it through parody, as in Ettore Scola's Le Bal, but to display it with its values more or less intact, for whatever they might be worth. On the one hand, this may reflect the commercial perspicacity of a director aware of demographic changes in the United States and the composition of the audiences to whom he must sell his movie, but, on the other, it also shows how far Hispanic tradition and the particular textualizations of Hispanic cultural practices have succeeded in penetrating cultural practices and their textualizations in the United States.

It is, in part, because of this dynamic in cultural practices that I am inclined to accept Spielberg's choice of a tango and of "Por una cabeza," in particular, for Schindler's List as a reflection of something more than Hollywood intuition. The choice was historically appropriate, as I have indicated, but I suspect that it may also have been motivated by an awareness that part of his audience would identify it and enrich their reading of his film, perhaps in the way I described earlier. I wonder too if there might not be more than coincidence to his choice of the same tango as that danced to by Al Pacino in Scent of a Woman. Spielberg, is often thought of as brilliant, but shallow, one of the reasons frequently cited to explain why recognition by the Hollywood establishment has eluded him. Even Schindler's List, which has been praised as his best work to date, has not escaped criticism, as I have already mentioned. Is it possible that he used 
"Por una cabeza" to respond to such criticism, not only to enrich the textualization of Schindler's introduction at the beginning of the film, but to imply that if Al Pacino's tango could win him an Oscar, then Spielberg's own Oskar, Schindler, that is, should, for the same song, garner a similar award? As it happened, the Academy Awards for 1994 made Spielberg a double winner with recognition for himself as best director and for his film as best picture: two Oscars for one tango, not to mention the other awards it also won - but that opens up another kind of cultural practice altogether.

\section{University of Alberta}

\section{NOTES}

1 Connerton defines a practice in part as " [...] an activity which is acquired in the sense that it is influenced by previous activity." (How Societies Remember, Cambridge: Cambridge University Press, 1994, p. 94).

2 The lyrics to South American tangos referred to in this paper may be found in Eduardo Romano's Las letras del tango : antología cronológica 1900-1980. (Rosario (Argentina): Editorial Fundación Ross, 1991). In the context of the tango to which it is the title, "Por una cabeza " literally translates as "Because of a head."

3 "It's absurd that I now want to relate what I was incapable of knowing well while it was happening, like in a parody of Proust I am trying to enter the memory as I could not enter life in order to live it for real at last." (Cortázar, "Diario para un cuento", Deshoras, Madrid: Ediciones Alfaguara, 1982, p. 150). My translation.

4 Here the phrase may be translated as "per head."

5 I have in mind articles such as that by Claude Lanzmann, first published on March 3, 1994, in Le Monde, and later in English in the Manchester Guardian Weekly, in which the very representability of the Holocaust is raised. In contrast to what I have already suggested, Lanzmann argues that the experience of some events is greater than the textualized memory of them.

6 See, for example, "Anclao en París," a tango with lyrics by Enrique Cadícamo and music by Guillermo Desiderio Barbieri, recorded by Gardel in 1931.

\section{WORKS CITED}

Connerton, Paul. How Societies Remember. Cambridge: Cambridge University Press, 1989.

Cortázar, Julio. “Diario para un cuento», Deshoras. Madrid: Ediciones Alfaguara, 1982, p. 137-173.

Lanzmann, Claude. "Why Spielberg has distorted the truth". Manchester Guardian Weekly (April 3, 1994) p. 14.

Romano, Eduardo. Las letras del tango: antologia cronológica 1900-1980. Rosario (Argentina): Editorial Fundación Ross, 1991. 